\title{
Would the control of invasive alien plants reduce malaria transmission? A review
}

\author{
Christopher M. Stone ${ }^{1}$, Arne B.R. Witt ${ }^{2 *}$, Guillermo Cabrera Walsh ${ }^{3}$, Woodbridge A. Foster ${ }^{4}$ and Sean T. Murphy ${ }^{5}$
}

\begin{abstract}
Vector control has been the most effective preventive measure against malaria and other vector-borne diseases. However, due to concerns such as insecticide resistance and budget shortfalls, an integrated control approach will be required to ensure sustainable, long-term effectiveness. An integrated management strategy should entail some aspects of environmental management, relying on coordination between various scientific disciplines. Here, we review one such environmental control tactic: invasive alien plant management. This covers salient plant-mosquito interactions for both terrestrial and aquatic invasive plants and how these affect a vector's ability to transmit malaria. Invasive plants tend to have longer flowering durations, more vigorous growth, and their spread can result in an increase in biomass, particularly in areas where previously little vegetation existed. Some invasive alien plants provide shelter or resting sites for adult mosquitoes and are also attractive nectar-producing hosts, enhancing their vectorial capacity. We conclude that these plants may increase malaria transmission rates in certain environments, though many questions still need to be answered, to determine how often this conclusion holds. However, in the case of aquatic invasive plants, available evidence suggests that the management of these plants would contribute to malaria control. We also examine and review the opportunities for large-scale invasive alien plant management, including options for biological control. Finally, we highlight the research priorities that must be addressed in order to ensure that integrated vector and invasive alien plant management operate in a synergistic fashion.
\end{abstract}

Keywords: Invasive alien plants, Biological control, Environmental management, Plant-vector interactions, Nectar feeding, Resting, Larval habitat, Vector-borne disease

\section{Background}

Malaria remains a major threat to human health in many parts of the tropical and sub-tropical regions of the world [1], even though significant progress has been made with the implementation of preventative measures such as insecticide-treated nets [2, 3]. In sub-Saharan Africa for example, the disease remains chronic in many countries, and while mortality rates have fallen, an estimated 855,000 deaths were caused by this disease in 2013 [4]. Although the use of insecticide-treated nets has significantly reduced infection rates, there is concern about the increase in insecticide resistance in Anopheles spp. (Diptera: Culicidae), the vectors of Plasmodium spp. [5]. For instance, various pyrethroid resistance mechanisms are now common throughout much of the western and central parts of Africa [6]. In the past,

\footnotetext{
* Correspondence: a.witt@cabi.org

${ }^{2}$ CABI Africa, 673 Limuru Road, Muthaiga, PO Box 633-00621, Nairobi, Kenya Full list of author information is available at the end of the article
}

pesticide use in agro-ecosystems also had a significant impact on malaria vectors, and likely has selected for insecticide resistance [7-9]. At the same time the natural enemies of mosquitoes continue to be negatively affected through the use of agro-chemicals [10]. As such, there is an increased risk that gains in malaria control will be negated, unless an integrated and sustainable approach is developed and implemented.

An integrated approach to vector control would manage factors contributing to mosquito reproduction, and longevity, in a sustainable and efficacious manner [11, 12]. Such strategies will rely on collaboration and coordination between multiple disciplines and societal stakeholders. Important cross-disciplinary research questions are those relating to (i) coordinating agricultural and vector control practices, given the selective pressures for resistance traits; (ii) understanding how changes in vegetation structure and composition (whether due to deforestation, to landuse changes, or to the spread of invasive plants - the last, 
the focus of this review) will affect pathogen transmission; and (iii) understanding the specific effect of plants on mosquito survival, biting frequency, reproduction, and vector competence. Emerging evidence from several sources indicates that many invasive alien plant (IAP) species may be particularly important in the enhancement of mosquito demographic parameters [13, 14].

Management of IAP species and control of vectorborne diseases such as malaria typically are not considered simultaneously. Yet, if there are sufficiently strong interactions between invasive plants and vectors, vectorcontrol activities targeted at one may impact the other, directly or indirectly. If such interactions are negative, policy makers will have to weigh the repercussions at the level of the environment, economic development and human health. If the interactions are positive, there may be exploitable synergies between control of invasive plant species and vectors. In this review we explore whether there are reasons to expect such interactions and review the literature on the topic. We focus on malaria, though resulting insights will likely apply more broadly and beyond mosquito-vectored pathogens. For instance, an accumulating body of evidence suggests that IAPs can affect the spread and transmission intensity of sleeping sickness as well as various tick-borne pathogens [15-18].

IAP species are now a major problem in Africa and other regions where they have significant negative impacts on crop and pasture production, human and animal health, water, and other natural resources [19-25]. These plants were introduced over the course of the last few centuries, either accidentally or deliberately, via increasing trade and transport. Most are now widely distributed and still spreading, a situation which is exacerbated by increasing disturbance, land transformation $[26,27]$ and climate change $[28,29]$.

Given their vast distributions, there are at least two important ways that IAP species may be significantly influencing the biology and malaria-transmitting ability of Anopheles spp. First, female and male mosquitoes need sugar sources for energy, mostly obtained from floral and extra-floral nectar, honeydew and fruits [30-32]. Secondly, many IAPs provide suitable habitats as resting or breeding sites for mosquitoes [33, 34]. An open question is whether and how these aspects of mosquito biology are different in environments dominated by invasive plants, and whether this has ramifications for the transmission intensity of malaria. The eventual aims of the research must be to confirm that Anopheles spp. are, in reality, more abundant, with better reproduction, survival, and other vectorial-capacity characteristics in the presence of IAPs and to confirm that malaria incidence is higher where there is an abundance of non-native plants. Present evidence indicates that this is true [35], but our knowledge of Anopheles plant hosts is meagre, and native plant species also are known to provide malaria vectors with benefits. The inferred links between Anopheles spp. and IAP species raises the associated question of whether the management of particular invasive plants would contribute to the suppression of Anopheles spp. populations and to a reduction in malaria incidence.

Currently, much of the relevant literature on these topics is scattered. Thus, the purpose here is to provide a review of the current state of knowledge about these topics and to identify the gaps in this knowledge. The review is divided into three major sections. The first covers the questions of whether Anopheles spp. benefit from IAPs and, if so, whether this has a positive influence on the rate of malaria transmission. We then turn to the questions of the potential for management of IAPs on a large scale; and finally, discuss whether invasive plant control is likely to result in a reduction in the incidence of malaria. Although the main theme of this review is the relation Anopheles mosquitoes have with IAPs, we have included studies of other genera of mosquitoes that contribute to a general understanding of the topics.

\section{Do invasive alien plants have a positive influence on the rate of malaria transmission?}

Measures of transmission rate: The basic reproduction number and vectorial capacity

Here, we focus on how and whether the presence of individual or various functional groups of invasive plant species may affect the rate of Plasmodium falciparum malaria transmission. An intuitive way to explore this is to focus on the basic reproduction number of malaria, $R_{0}$, its constituent parameters, and how those parameters are affected by functional traits or ecosystem impacts typically associated with invasive plant species.

The basic reproduction number provides an estimate of the number of new infections in humans following the introduction of a single infected case into a fully susceptible population [36]. It is described by the following eq. [37]:

$$
R_{0}=\frac{m a^{2} b c e^{-\mu \tau}}{\gamma \mu}
$$

This can be understood as the product of the number of mosquito bites per person per day $(m a)$, the duration a typical human remains infective $\left(\frac{1}{\gamma}\right)$, the probability of a mosquito becoming infected upon biting $(c)$, the probability of a mosquito surviving the extrinsic incubation period $\left(e^{-\mu \tau}\right)$, the number of bites per mosquito over its expected lifespan $\left(\frac{a}{\mu}\right)$, and the probability that an infectious bite will establish an infection in a human $(b)$. 
Certain of these vector-related properties can be broken down further. For instance the biting rate of mosquitoes on humans, $a$, can be seen as the product of the inverse of the average time between blood meals and the preference to bite humans over other types of animals, such as cattle [37].

Vectorial capacity is a measure strongly related to the basic reproduction number. It was initially defined by Garrett-Jones [38] and isolates the entomological parameters from $R_{0}$. Vectorial capacity, $C$, relates to $R_{0}$ as $R_{0}=\frac{b}{\gamma} C$ [37]. It represents the number of potentially infective bites that would result from an infected human being exposed to a mosquito population for a single day, and it provides a useful lens through which to explore the link between vector traits, IAPs, and malaria transmission.

All these vector traits, including complications such as senescence or traits that can lead to heterogeneous exposure, such as biting preferences or vagility, may be affected by plant-species composition and abundance in a given area. Evidence for this as it relates to nectar-feeding by mosquitoes has recently been reviewed [39]. Furthermore, theoretical calculations of the impact of attractive toxic sugar baits for malaria control demonstrate that the availability and distribution of plant-nectar sources are significant determinants of malaria inoculation rates [40]. Here, we summarize these plant-vector interactions briefly and highlight other potential effects of plants on vectors, particularly those associated with IAPs.

\section{The relationship of mosquitoes and plants}

It has been known for over a century that adult mosquitoes are, in part, phytophages that feed on sugar sources from nectar and other plant juices [30, 41, 42]. Females need blood mostly to mature their eggs [43], although some nourishment is obtained from blood itself in most species [44]. Blood meals can come from a wide variety of hosts, perhaps even other insects, so mosquitoes are eminently plastic host feeders $[45,46]$. The few instances of stenophagy, as is the case of Anopheles gambiae (s.s.) on humans, is also particularly relevant, because this specificity is part of its great efficiency as a malaria vector [45]. Although the females of some mosquito species seem to be blood specialists [47], even these females still feed on sugar during certain age and reproductive stages or under conditions of host- or oviposition-site scarcity [48-50].

Many different plant species are fed on, but not all plants have the same attractiveness, or effect on survival and flight [31, 32, 51-53]. Yet laboratory experiments on An. gambiae [54] indicated that any plant was better than no plants, even Lantana camara L. (Verbenaceae), a species reported to have mosquito-repellent properties [55]. Furthermore, plant choice can show seasonal, diel, and even sexual differences [32]. The extent and consequences of plant dependence on the ecology of adult mosquitoes and their vectorial capacities is a field of active research.

A currently less explored relationship between mosquitoes and plants is that between larvae and aquatic plants. Mosquitoes have aquatic larvae, and a great many different kinds of interactions can be expected between larvae, ovipositing adults, and aquatic plants. This issue was first approached in the Americas in the early twentieth century in relation to malaria outbreaks in the southeast USA and the Panama Canal area [56-58]. In those days it was considered that malaria control would be achieved essentially through larval control. In fact, the only instances in history of successful mosquito eradication (Aedes and Anopheles spp.) were achieved mainly by targeting larvae and breeding site management, as in the cases of An. arabiensis eradication in Brazil and Egypt between the 1930s and 1940s [59-61]. But since the appearance of DDT in the 1940s, mosquito control has concentrated on adult control, and as a result many knowledge gaps on larval ecology of mosquitoes persist [62]. However, concerns about insecticide resistance, environmental impacts, rising costs of indoor spraying, and logistical constraints, have sparked renewed interest in larval control of malaria vectors $[60,62]$.

\section{Nectar-plant contribution to transmission pressure}

For most of the traits that determine the vectorial capacity of malaria mosquitoes, there is ample evidence that they are affected by plants. The effect of access to different plant species and their nectar on mosquito survivorship has been studied in detail. For instance, while access to nectar consistently increases longevity, there are large differences between different plant species with regard to their effect on longevity [50, 51, 54, 63, 64]. Besides the effect of nectar quality, abundance, and accessibility, some plants also provide mosquitoes with shelter: certain plants may create more suitable microclimates facilitating mosquito resting behaviour and diurnal survival. The extent to which this contributes to mosquito survivorship may depend on the mosquito species in question or the environment (e.g. the need or tendency to rest outdoors). The importance of such harbourage is not well-known, and resting behaviour in general remains an understudied aspect of mosquito biology.

The effects of plant nectars on the biting frequency of mosquitoes are less clear. In certain experiments, the biting rate is decreased when mosquitoes have ad libitum access to sugar sources $[50,65,66]$. In other cases, the biting rate is unaffected [67] or greater [64] with access to nectar-bearing plants or plants that are more attractive and/or produce more copious amounts 
of nectar. This discrepancy could be due to differences in host availability. For instance, mosquitoes are more likely to feed on nectar, and take larger meals, when blood hosts are available for only a short period of the night or at times that do not coincide with the species' peak biting activity [68]. This would suggest that under natural field conditions where blood hosts are abundant and easily accessible, plants may have little impact on the biting frequency but affect other aspects of vectorial capacity and reproduction [67].

The development of Plasmodium within the mosquito may also be affected by feeding on different plant species. This development includes both the probability of the pathogen reaching the infective sporozoite stage (i.e. vector competence) and the average length of time between ingestion of a gametocytemic blood meal and appearance of sporozoites in the salivary glands (i.e. the extrinsic incubation period of Plasmodium). Besides sugars, nectar contains amino acids and secondary metabolites. These various compounds, either directly or indirectly (e.g. by affecting the mosquito's immune response), may have an impact on pathogens within the vector. For instance, in An. coluzzii, females that had access to the fruit Lannea acida A. Rich. (Anacardiaceae) or the flowering ornamental plant Barleria lupulina Lindl. (Acanthaceae) were more likely to have disseminated sporozoites in their heads and thoraxes after an infectious meal than females that were exposed to a different ornamental, Thevetia neriifolia Juss. ex Steud. (Apocynaceae) [69].

The impact of plant-nectar on mosquito population density is complex, as numerous traits will affect this outcome. These traits will include female fecundity and survival. Studies that have measured the impact of sugar on the net reproduction rate of mosquito populations indicate a depressing effect of sugar [39]. However, because fecundity in mosquitoes is strongly correlated with the biting rate, this may not hold under field conditions (e.g. if differences in fecundity are merely a result of differences in the biting frequency). Another complication is that the regulation of mosquito population density, particularly of Anopheles spp., under natural conditions remains poorly understood. While seasonal changes in rainfall are clearly an important driver of population densities, density-dependent larval development may be relevant for part of the year or in certain larval habitats. If larval habitats are at carrying capacity during mid- to late rainy season, differences in population growth rates may not result in different population sizes.

The growth rate of a population can also be influenced through effects of plants on male mosquitoes. For male mosquitoes, feeding on nectar provides their sole source of nutrients. Without nectar, their prospects of survival and mating dwindle. Laboratory cage and mesocosm experiments indicate that in the absence of nectar, insufficient females may become inseminated to sustain a population [70,71]. Whether this is applicable under natural conditions, where nectar sources may vary in attributes such as quality, quantity and accessibility, but likely are not entirely absent save for the most inhospitable environments, is not yet resolved. Females may not become inseminated until a later age in areas where sugar is inaccessible [67], and presumably such a delay in female reproduction affects the population growth potential.

\section{Plants and mosquito oviposition and larval development}

The effect of aquatic plants on mosquito oviposition and larval development has received the most attention. Most studies indicate that some aquatic plants, both macrophytes and charophytes, boost mosquito reproduction or larval survival, while others inhibit it, often in contradictory reports [72]. The evidence suggests that aquatic plants contribute to the spread of many human diseases around the world, including malaria [14], although not all vectors respond the same way to them. The general description of breeding sites for An. gambiae (s.l.) are small pools or puddles with diameters less than $1 \mathrm{~m}$, while vegetation is considered crucial for the breeding of An. funestus (s.l.) [73-77]. For instance, in the Lake Victoria region in East Africa, the most aggressive Anopheles spp. were not abundant in deep permanent lake waters, even if invaded by the IAP Eichhornia crassipes (Mart.) Solms (water hyacinth, Pontederiaceae) and other aquatic weeds. However, they bred abundantly in temporary or seasonal aquatic coastal habitats such as pools and swamps, more so when infested by aquatic vegetation [78]. Although experimental evidence is scarce, there are plenty of observational reports of a relationship between larval abundance and aquatic vegetation. Water lettuce, Pistia stratiotes L. (Araceae), the main host of Mansonia spp. mosquitoes, was also reported as a plant that favoured anopheline establishment $[79,80]$. So were water primroses, Ludwigia spp. (Onagraceae) [81], another genus with several species that are invasive in many countries. The South American invasive plants E. crassipes, Egeria densa Planchon (Brazilian elodea; Hydrocharitaceae), Hydrocotyle ranunculoides L. (floating pennywort; Araliaceae), and water lettuce, were deemed to increase the risk of the return of malaria in Europe [82]. Water hyacinth and Myriophyllum aquaticum (Vell.) Verdc. (parrots feather; Haloragaceae) were also reported to stimulate anopheline reproduction in the USA [72, 81, 83]. Curry [57] and Rozeboom [58] stated that submerged species in the genera Chara (Characeae), Utricularia (Lentibulariaceae) and Najas (Hydrocharitaceae) provided vast breeding sites for An. albimanus, the 
most important malaria vector in the Americas. Studies in India state that aquatic plants, especially water hyacinth, were associated with increased Anopheles spp. richness, though not abundance [84]. In fact, aquatic weed control is a standard procedure in mosquito management [62].

Field studies using systematic samplings and statistical analyses (PCA and other multivariate analyses) corroborate the important role of aquatic plants in mosquito abundance. Rejmánková et al. [85] predicted biting risk for An. albimanus based on wetland characteristics with a 90 to $100 \%$ precision. These characteristics were emergent macrophytes, water hyacinth, dense cyanobacterial mats, and distance to the nearest human community. Subsequent studies by Rejmánková et al. [86, 87] confirmed that submersed and floating plants, and cyanobacterial mats were associated with Anopheles spp. abundance in Belize and Mexico. In Argentina, Anopheles spp. abundance, as well as that of several other species, was associated with the emergent/floating macrophytes $H$. ranunculoides, Alternanthera filoxeroides Grisebach (alligator weed; Amaranthaceae) and Ludwigia spp., as well as water lettuce and the floating ferns Salvinia spp. (Salviniaceae), all of which are important IAPs in many parts of the world. The chemical properties of the water courses sampled were not a relevant factor in the statistical analyses [88, 89]. Similar results were obtained in Mexico, where the dominant factor was water hyacinth during the dry season, and emergent Cyperaceae during the wet season [90]. Sinka and collaborators $[75,76,91]$ published three extensive spatial analyses and reviews of the available knowledge on occurrence, distribution, and ecological requirements for the 41 main malaria vectors in the world. The data they obtained from their meta-analyses showed that some Anopheles spp., including the An. gambiae complex, are typically found in small water bodies devoid of plants, but most species are associated with aquatic plants and plant debris. Yet, even the $A n$. gambiae species are often found in abundance in plant dominated waters. This was attributed to the typical adaptability of mosquitoes and to differences in behaviour at population level.

Azolla (Azollaceae) and Salvinia (Salviniaceae), two genera of floating ferns, and duckweeds (Araceae), have been reported both to prevent and favour mosquito establishment [92-94]. Salvinia spp. were proposed as a mosquito control option, acting apparently by simply providing a physical barrier to ovipositing females [93]. In the case of Azolla spp., the plant was described as trapping emerging adults in the multi-layered and multidissected fronds [95]. On a closer look, however, it would seem that the main factor is not so much plant species, but density $[86,96]$. Pool experiments and systematic sampling of rice fields suggest that duckweed and aquatic ferns may hinder mosquito growth at high densities, but stimulate it at low densities [97, 98], and more than $80 \%$ cover by Azolla spp. must be kept, to provide mosquito control in rice paddies [98, 99]. Yet, the highest densities of fish that serve as mosquito predators occur at intermediate plant densities. Both very high and very low plant densities in lakes were associated with seven-fold reductions in fish densities [100]. Thus, despite the vector-suppressing aspects of aquatic vegetation, managing their densities at optimum levels may be unrealistic. Furthermore, severe invasive plant infestations often contribute to other problems, such as the loss of aquatic biodiversity, fouling of water resources, and the promotion of snail populations that serve as intermediate hosts of the blood fluke Schistosoma [101, 102].

There have been a few experimental approaches to understanding the relationship between mosquito breeding and aquatic plants. Furlow \& Hays [97] planted pools with different aquatic plants, with a clean pool as a control, and allowed spontaneous mosquito colonization. The clean pools, and those with submerged macrophytes produced more Anopheles spp. than those with a thick duckweed cover. Orr \& Resh [103] evaluated experimentally the relationship between plant cover and predation of mosquito larvae. Experiments whereby algae were mechanically extracted from natural streams demonstrated that water devoid of filamentous algae harboured dramatically fewer Anopheles larvae [104, 105]. The experimental and observational evidence indicates that the way aquatic plants benefit mosquito larval survival is by protection from predators [83, 103, 104, 106, 107], increased food availability [83, 104, 108], and dampened wind action [77, 108-110]. It is evident, then, that large, open, wind- and predator-exposed waters are deleterious to Anopheles spp. larvae in general.

Both terrestrial and aquatic vegetation affect immature mosquito dynamics in a number of ways. One way is by influencing where mosquitoes lay their eggs, which could affect local population densities. For instance, Aedes albopictus females appear to have a preference to oviposit in sites adjacent to flowering plants (Buddleja davidii Franch; Scrophulareaceae) [111]. Likewise, up to a certain density of Myriophyllum aquaticum cover, the oviposition activity of Anopheles hermsi was increased [83]. In choice tests, An. gambiae is more likely to oviposit on bare soil than on water near grassy vegetation [112], while An. minimus (s.l.) prefers to oviposit on water near small-leaved plants [113]. In The Gambia, presence of anopheline larvae was positively associated with short emergent vegetation or tufts of grass, but was lower in sites where taller vegetation shaded more than $25 \%$ of a potential larval site [114]. The latter insight is well established for certain sun-loving vectors and has 
led to the planting of species providing dense shade to control vectors. For instance, in Java, An. maculatus populations on tea plantations were managed by planting the invasive alien shrub Tithonia diversifolia (Hemsl.) A. Gray (Asteraceae) [115].

Terrestrial plants also can impact larval development through input of plant materials into water bodies. A well-known example is the deposition of maize pollen into larval habitats. In the vicinity of maize fields, larvae develop into adults with greater probability, do so more rapidly, and produce larger-bodied adults [116]. Larvae also were found to develop into adults despite conditions of intense crowding, if they were near areas where maize pollen was abundant [117]. The importance of the input of plant material in the form of leaf litter, fruits, or flowers is well established for the larvae of container- or treehole-breeding mosquitoes [13]. Additionally, certain IAPs can serve as harbourages for adults (e.g. Amur honeysuckle, Lonicera maackii Rupr; Caprifoliaceae) and support greater mosquito densities [118, 119]. The importance of such inputs for malaria mosquitoes in particular is less clear.

\section{Do mosquito interactions with invasive alien plants cause differences in transmission?}

Does malaria transmission pressure differ between pristine and invaded landscapes? There are at least two ways by which vector-borne pathogen transmission might increase when invasive plants become established. The first would occur where an IAP establishes itself in a barren or early successional environment, or reaches a greater biomass (and therefore provides more adult refugia and nectar) than the plant species it replaced. The second scenario would occur when an IAP possesses traits that change the functioning of an ecosystem in a manner that enhances a vector's vectorial capacity by altering its components.

A wide variety of ecological and evolutionary hypotheses have been posited as potential explanations for what makes particular species successful invaders, many of which allude to particular traits that allow for invasiveness [120-124]. These include the ideal-weed hypothesis, which suggests that a weed possessing life history traits such as early and high fertility, small seed size, and rapid growth would tend to have a competitive advantage. IAPs may have an advantage due to biotic release from enemies (enemy release hypothesis), whereby herbivores or pathogens that limit population growth in the native habitat are absent in invaded habitats. This would potentially allow for resources initially allocated to defences to be diverted to increased fertility or growth (evolution of increased competitive ability) [125-127]. Alternatively, invasive plants may release allelopathic chemicals to which native species are not adapted (the novel weapons hypothesis). Invasion success can also be related to increased resource availability, disturbances, or the presence of empty niches [121]. The diversity of these hypotheses (e.g. Catford et al. [121] describe 29 different ones) highlights the complexity involved and perhaps bodes caution when trying to link interactions of vectors with a group of organisms as broadly defined as "invasive alien plants". However, many of these hypotheses do relate at least in part to biotic traits of the invasive organism. Further, invasives are often identified as such by their ecological or economic impact. To the extent that such broader ecosystem impacts are comparable among different invasive species, these characteristics may apply to mosquitoes as well. The questions of interest are then, which traits and impacts are well supported, and how do those traits intersect with the manner in which mosquitoes rely on local plant communities?

A number of such traits that could affect mosquitoes have been identified through large-scale comparative studies. These have shown that for a variety of traits related to plant physiology, including allocation of resources, growth rate, size, and fitness, invasive plants had greater trait values than native species [128]. Traits linked to invasiveness include a fast growth rate and vigorous spatial growth, particularly for IAP species in tropical areas [128], as well as greater photosynthetic rate and efficiency of water and $\mathrm{N}$ and $\mathrm{P}$ usage [129]. Potentially more salient findings, with regard to mosquitoes, are that IAP species have been found to be taller in their native range [130-132] (potentially affecting shading of habitats), and they have a different flowering phenology, either flowering longer than native plants [132-136] or tending to flower earlier or later [130, 137]. The majority of these studies were undertaken in temperate or Mediterranean ecosystems and therefore must be extrapolated with care to Afro-tropical regions. Such extended or earlier flowering periods, could, if associated with an extended or earlier production of nectar, enhance mosquito survival and population growth during periods when native plant communities might not support mosquito reproductive success.

A body of work also exists on ecosystem impacts associated with invasive species. For instance, water usage of plants, considered at an ecosystem scale (rather than at the level of an individual plant or even leaf), when evaluated within each growth form (grass/sedge, forb/fern, or tree/shrub), was found not to differ significantly between native and invasive plants. But a comparison among all growth forms pooled together showed that on average ecosystems dominated by IAPs had a $50 \%$ higher rate of evapotranspiration than those dominated by native plants [138]. Whether this might affect the microclimates of mosquito immatures (e.g. abundance of standing water) or of adults (e.g. humidity) is an open 
question. Further, IAPs have been found to decrease local plant abundance and species richness, but increase total community productivity (as measured in plant biomass or net primary productivity) [27]. The fitness as well as the abundance of animals also was lower, the latter by approximately 17\% [27]. Likewise, an increase in biomass and reduction in plant diversity, causing a reduction in vertebrate animal abundance, may affect mosquito populations as well. This can cause a shift in host utilization of generalist blood-feeders such as $A n$. arabiensis, resulting in a higher biting rate on humans. For instance, many IAPs are toxic and reduce pasture carrying capacities [23-25]. If this leads to a severe reduction in cattle near human habitations, this would result in higher biting rates on humans, due to reduced availability of domestic animals or to a genetic shift to a greater preference for human hosts. Malaria rates could be further exacerbated by any economic impacts of a loss of pasture. If invasive plants also affect nondomestic animals that do not serve as blood sources, including predators, competitors, pollinators, and honeydew producers, outcomes for the mosquito population become difficult to predict. Invaded ecosystems do tend to have a depauperate insect fauna, including fewer parasitoids and predators, and fewer phytophagous insects [139-145], which can result in a reduction in insectivorous birds [146-149]. It seems plausible, then, that such shifts in invertebrate diversity and abundance could favour mosquitoes, but this remains to be confirmed.

Evidence is scant that IAPs differ from non-invasive species in ways related directly to the fitness or vectorial capacity of vectors, and only a few studies have tested this explicitly. Traits having a direct effect would most likely relate to harbourages and to nectar, both of which can increase survival of adults. Features of favourable daytime harbourages may include plants that provide greater protection from wind, low humidity, direct sunlight, and excessive heat. Features of nectar that favour mosquitoes are its quantity and concentration, and the ease with which it can be accessed. The amount of accessible nectar is determined by physical characteristics of the inflorescence, interactions with invertebrates such as spiders or ants, and competition with pollinators, parasitoids, or other nectar feeders. Such tritrophic interactions have received little attention to date, and outcomes could conceivably go either way. For instance, if IAPs tend to escape from pathogens and herbivores, they may have less of a need to invest in the production of extra-floral nectar to encourage ants. On the other hand, if invasive plants are able to invest more energy into reproductive output, for instance by flowering and producing nectar for a longer period, and invertebrate communities tend to be diminished, this could result in a greater availability of nectar for mosquitoes.
A number of studies have assessed the survival of $A n$. gambiae when provided with access to a variety of native and alien plants (though typically that distinction was accidental). In those studies, the plants that allowed the greatest longevity were those invasive in parts of Africa such as Ricinus communis L. (Euphorbiaceae) [51], Manihot esculenta Crantz (Euphorbiaceae) [62], and Tecoma stans (L.) Juss ex Kunth (Bignoniaceae) [54] (Fig. 1). Other IAPs however, such as Lantana camara, appear to provide only very little nectar and support longevities of only a few days $[50,51,54,150]$. The same appears true of the weed Parthenium hysterophorus L. (Asteraceae) [54] (Fig. 1), although in one study this weed provided ample sugar and supported mean lifespans much closer to that of $R$. communis [151]. Whether such discrepancies are due to differences in experimental set-up (e.g. the condition of plants or cuttings that were used) or underlying genetic or environmental differences between plant populations, is an important open question. If there are extremely large differences in nectar production between populations of the same species of plant, recommendations for management will become that much more complicated.

Equally important is whether mosquitoes will locate and attempt to feed on nectar from non-native plants. A priori, one might assume that given the importance of nectar-feeding for mosquito reproductive success, mosquitoes will have evolved to respond most strongly to the volatiles of nectariferous plants native to their region. An alternative hypothesis is that the volatile organic compound blends released by plants provide a clue to their nectar productivity, and mosquitoes are able to detect such state-dependent cues. There is some support for the latter notion. For instance, when given access to a panel of plants, those that the mosquitoes perched on most often (i.e. were attracted to, or retained on the longest, in a cage) were also the plants that resulted in the greatest proportion of sugar-fed mosquitoes after exposure in a no-choice test, and these included a mix of native and alien plants [31]. Olfactometer experiments likewise have shown that both native [e.g. Senna didymobotrya (Fresen) H.S. Irwin \& Barneby; Fabaceae,] and alien ( $P$. hysterophorus) species to tropical Africa to be among the most attractive plants to An. gambiae (Fig. 1). In Mali, the most attractive flowering plants were Acacia macrostachya DC (Fabaceae), Faidherbia albida (Delile) A.Chev. (Fabaceae), Boscia angustifolia A. Rich (Capparaceae) and Ziziphus jujube Mill. (Rhamnaceae) [32], only the latter of which is an alien species and can become invasive in certain regions. In Burkina Faso, the most attractive plants were reported to include Mangifera indica L. (Anacardiaceae), Delonix regia (Hook.) Raf. (Fabaceae), Thevetia neriifolia, Senna siamea (Lam.) H.S. 


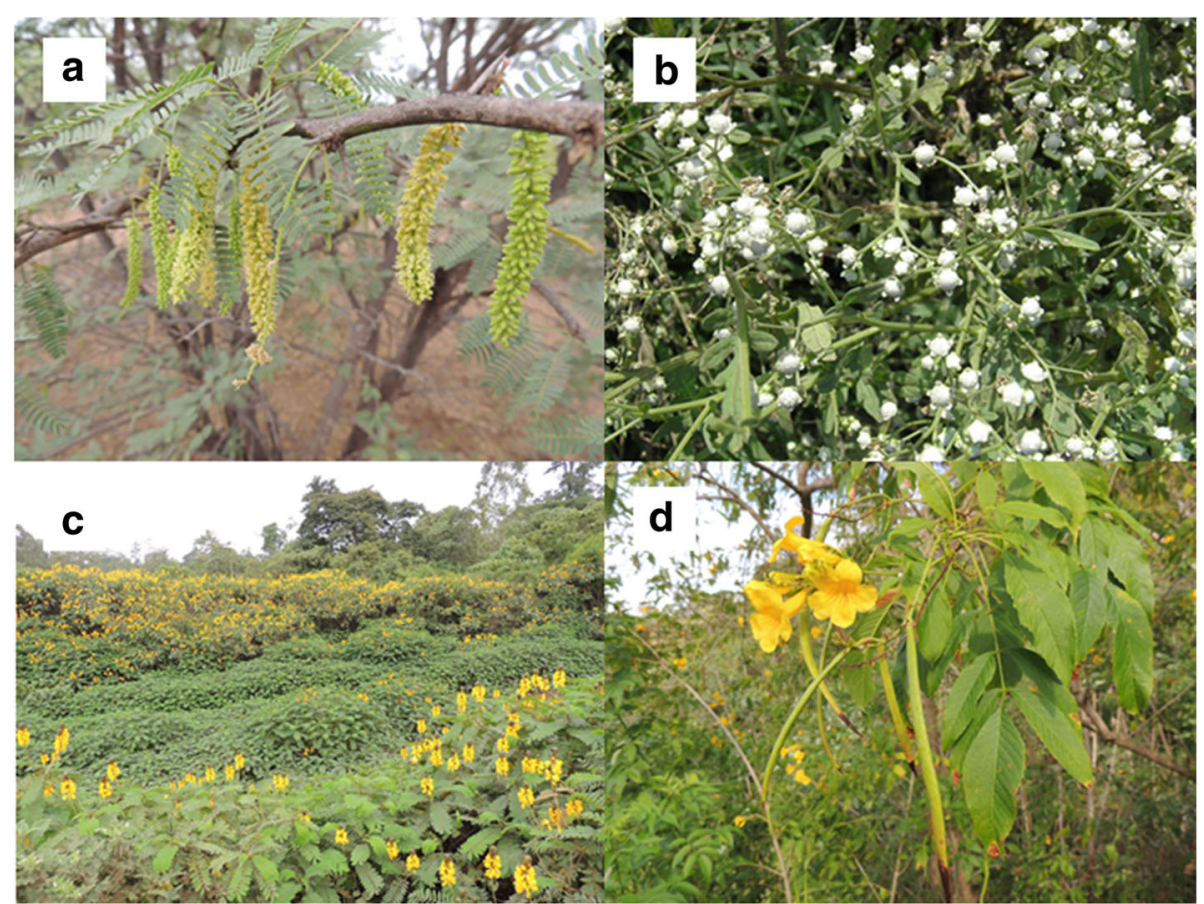

Fig. 1 Invasive plant species in Africa known to be attractive to malaria vectors include Prosopis juliflora (a), Parthenium hysterophorus (b), Senna didymobotrya $(\mathbf{c})$, and Tecoma stans (d)

Irwin \& Barneby (Fabaceae) and Cassia sieberiania DC (Fabaceae) [52], of which only the last is native to equatorial mainland Africa. This is further supported by a recent study finding that An. gambiae benefitted from the presence of the introduced invasive shrub Prosopis juliflora (Sw.) DC (Fabaceae) in Mali [35] (Fig. 1). Thus, there is little support for the notion that mosquitoes would favour plants with which they have co-occurred for longer (evolutionary) periods. Attraction studies that account for the state or condition of various plants could shed more light on this issue.

Finally, very little is known of the importance of biomass or abundance of different plants on the foraging decisions made by mosquitoes. Presumably (given that preferences for different plant species are not absolute), the plants that are fed on in a given locale will be a function both of their attractiveness or acceptability to mosquitoes, and of their abundance or how frequently plant species are encountered. This is particularly important for malaria mosquitoes such as An. gambiae, because sugar feeding and blood feeding are, to an extent, energetically interchangeable in this species. Thus, changes in plant abundance or biomass might affect not only which plants are used, but the rate at which humans are bitten.

To summarize, while traits and ecosystem impacts of IAPs appear highly variable and context dependent, those with the broadest support appear to be longer flowering durations, more vigorous growth (which may result in more flowers), and potentially an increase in biomass that provides more daytime shelter, sometimes in areas where previously little vegetation existed. Additionally, many IAPs may provide mosquitoes with ample nectar, increasing their longevity in the field. While one might expect mosquitoes to favour plants with which they have interacted over evolutionary time, alien plants are often among the most attractive plant hosts. So although many questions remain, it is at least plausible that invasive plants will increase malaria transmission rates.

\section{The potential for invasive alien plants to be managed on a large scale Invasive alien plant management}

IAP management strategies need to include activities related to prevention, to early detection and rapid response, and to control. As most IAP species were intentionally introduced, the most effective way to preclude introductions into other regions is to prevent them. As such, a risk assessment of a plant's potential for invasiveness should be undertaken prior to its introduction in these regions. Evaluated species that are deemed to pose a risk to natural resources, agriculture, or human and animal health should never be imported intentionally. The risk of unintentionally introducing invasive or potentially invasive species, 
especially in contaminated imports, can be reduced by imposing better controls at all ports of entry. If the authorities or designated officials have failed to prevent the introduction of an invasive or potentially invasive species, and it has established in the field, it is critical that it be detected early and eradicated, if possible, before it becomes widespread and abundant. To that end it is important that a surveillance strategy be developed and implemented so that small and isolated invasions can be contained and eradicated. If surveillance did not result in the early detection of a potentially problematic plant, and eradication is no longer feasible because it is already widespread and abundant, it is essential to implement a control strategy.

Control strategies can include the use of cultural, physical, chemical or biological methods or a combination of some or all of these measures, followed by rehabilitation or restoration. Cultural control (e.g. the use of fire, flooding or grazing, to reduce the abundance of invasive plants) can be effective on its own, or when used in conjunction with other control methods. Fire is especially effective for controlling succulents such as species in the Cactaceae and Crassulaceae, and can also be used to reduce the abundance of young seedlings or saplings of other IAP plants, even grasses. Total inundation of semi-aquatic plants by water, through controlled flooding, can also be used to manage semi-aquatic IAP species. Livestock, such as goats, are sometimes also used to control palatable terrestrial weeds, although results have been mixed - livestock can often contribute to the further spread of invasive plants.

Manual control involves the direct removal of the above-ground parts of a plant with an axe, saw, chainsaw or slasher, or the uprooting of plants using a hoe, garden fork or spade, or by hand pulling. Removal of the above-ground parts of a plant is suitable only for those weeds that do not coppice or regrow from the rootstock. Manual control may also include ring- and strip-barking of large shrubs or trees. Mechanical control may involve the use of heavy machinery or equipment (e.g. bulldozers or tractors and can, among others, involve pushing, stick-raking, blade-ploughing and/or chaining of larger plants or medium density infestations). There are a number of advantages of manual control in that practitioners require little training or supervision; tools are simple, cheap and easily obtainable. In most cases, little or no harm is caused to the environment and manual control can be used in countries where no herbicides are registered for use against a particular IAP species. However, there are disadvantages, as it often includes procedures that are labour intensive, and as such can be expensive in countries with high labour costs; it is physically demanding and slow, and it usually requires repeated follow-up operations; where machinery is used, manual control can be expensive - incurring fuel and maintenance costs; soil disturbance may stimulate seed germination among weeds, and on steep slopes or on riverbanks this may also exacerbate soil erosion; and in dense infestations, native species are often inadvertently damaged or removed.

Chemical control is the use of herbicides, applied alone or in combination with other methods and can be applied in several ways. Foliar spraying is the use of a diluted herbicide sprayed over the foliage (leaves and stems) of seedlings, shrubs, grasses or dense vine infestations to the 'point of runoff'. Basal stem applications usually are applied to thin-barked woody weeds, tree saplings, regrowth and multi-stemmed shrubs and trees. The entire circumference of the trunk or stem from ground level to a height of $30-100 \mathrm{~cm}$ is sprayed or painted. Total frill involves the use of a hand-axe, panga, or machete, whereby horizontal cuts into the sapwood tissue of the stems or trunks of trees, vines or woody weeds, and then inserting herbicide into the cuts. Stem injection, sometimes also called drill-and-frill, involves the use of a battery-powered drill or similar tool. Holes are drilled (at a $45^{\circ}$ downward angle) into the stems or trunks of trees, cacti, vines or woody weeds, and herbicides injected into the drill hole, using a squeeze bottle or plastic syringe. Stump applications involve the cutting down of a plant at the base of the stem and then immediately applying herbicide to the stump. Cut stump, sometimes also referred to as "cut and spray" or "lopping/pruning" involves the felling of a plant completely at its base (no higher than $15 \mathrm{~cm}$ above the ground), preferably horizontally by chainsaw, brush-cutter, or similar tools and then applying herbicide (with a paint brush, a squeeze bottle, a sponge-tipped bottle or a spray bottle) to the cut stump. Scrape and paint involves scraping a very thin layer of bark from a $10-30 \mathrm{~cm} \mathrm{sec}-$ tion of stem (taking care not to cut through the vine), and then applying the herbicide to the exposed green underlying soft tissue before the plant can seal.

The main advantage of chemical control is that it is more cost-effective than other methods, especially manual control. Other advantages include the fact that results are quicker than with manual control, especially when compared with ring-barking or stripping, and that use of the correct herbicides, applied according to label recommendations, can have little to no negative impacts on the environment. However, there are also disadvantages, including the purchase of specialized equipment and the training of applicators, which can add to costs; herbicides can be expensive, especially if incorrect formulations are used, resulting in poor control and requiring repeated applications; target species must be 
'healthy', and weather conditions suitable, at the time of a herbicide's application; foliar applications can affect non-target species; herbicide misuse may cause environmental damage; and manual control of plants may be necessary before herbicide application. Also, widespread misuse of herbicides can produce severe environmental and health impacts $[152,153]$.

Biological control, that is, the use of host-specific natural enemies (pathogens, mites, and insects) to control invasive plants, has been practiced for many decades by a host of countries, especially the USA, Australia, South Africa, Canada and New Zealand. Over a period of 150 years, until the end of 1996, more than 350 species of invertebrates and pathogens were deliberately released in 75 countries for the control of at least 133 weed species [154]. It was estimated [155] that by the end of 2012, there were 1555 separate and intentional releases of 469 species of invasive-plant biological control agents against 175 species of invasive plants (when related taxa of unidentified plant species, such as some Opuntia spp. (Cactaceae), are counted as single target plants). These so-called 'classical' biocontrol projects have been conducted in a total of 90 countries [156]. At the national level, biocontrol programmes have achieved success rates of $83 \%, 80 \%, 61 \%, 51 \%$ and $50 \%$, respectively, in New Zealand [156], Mauritius [157], South Africa [158], Australia [159] and Hawaii [160]. Analyses undertaken in South Africa more than 20 years ago revealed that six invasive alien plants out of 23 targeted were under complete control, and a further 13 under substantial control [161]. In Hawaii, more than 25 years ago, seven introduced weeds out of 21 were already under complete control, and substantial control had been achieved for three more [160]. In Australia, of 15 completed programmes, 12 resulted in complete control [159]. In South Africa, without biological control, the area occupied by the invasive cactus Opuntia aurantiaca Lindl. (Cactaceae) could have been 15 times greater than it is today [158]. Thanks to biological control Opuntia ficus-indica (L.) Mill (Cactaceae) invasions in South Africa have been reduced by approximately $90 \%[162,163]$. In fact the introduction of host specific and damaging agents has probably contributed $75 \%$ to the control of species in the family Cactaceae [164].

Some examples of biological control programmes against IAPs that have achieved some degree of control are given in Table 1. In general, programmes against aquatic species have, to date, achieved a high level of success.

The main aim of biological control is to suppress plant vigour, reduce seed production, slow plant growth, and reduce the density of the plant infestations. The main benefits of biological control according to Greathead [176] are these: agents establish self-perpetuating populations, often throughout the range of a target weed, including areas that are not accessible using chemical or mechanical control methods; the control is permanent; there are no negative impacts on the environment; the cost of biological control programmes is low, relative to other approaches, and requires only a one-off investment; benefits can be reaped by many stakeholders, irrespective of their financial status or contribution to the initial research process. Biological control also can be used to resolve "conflicts". Many woody invasive species are widely promoted and disseminated for fuel wood in developing countries but also have negative impacts on livelihoods. Host-specific and damaging agents that attack only the reproductive parts of the plant can reduce spread and densification without reducing the beneficial attributes of the target species and in this way resolve the "conflict". However, it should

Table 1 Examples of biological control programmes against aquatic and terrestrial invasive alien plants

\begin{tabular}{|c|c|c|c|}
\hline Plant species & Family & Country/Region of control & Reference \\
\hline \multicolumn{4}{|l|}{ Aquatic invasive plant target } \\
\hline Pistia stratiodes $\mathrm{L}$. & Araceae & USA; Africa & {$[165,166]$} \\
\hline Azolla filiculoides Lamarck & Salviniaceae & South Africa; Europe & {$[167,168]$} \\
\hline Salvinia molesta D. Mitch & Salviniaceae & Global & [169] \\
\hline Myriophyllum aquaticum (Vell.) Verdc. & Haloragaceae & South Africa & {$[166,170]$} \\
\hline Alternanthera philoxeroides Griseb. & Amaranthaceae & Australia; New Zealand; Thailand; USA & [171] \\
\hline \multicolumn{4}{|l|}{ Terrestrial invasive plant target } \\
\hline Prosopis spp. & Fabaceae & Australia & {$[172,173]$} \\
\hline Acacia spp. & Fabaceae & South Africa & {$[174]$} \\
\hline Parthenium hysterophorus L. & Asteraceae & Australia & {$[175]$} \\
\hline Ageratina adenophora (Spreng.) R.M. King \& H. Rob & Asteraceae & USA (Hawaii) & [159] \\
\hline Chromolaena odorata (L.) R.M. King \& H. Rob. & Asteraceae & Ghana; Indonesia; Marianas; USA (Guam) & [159] \\
\hline
\end{tabular}


be noted that biological control agents are not available for every IAP species; some released agents have had negligible impacts on the target species; and there are situations where an agent has a significant impact on the target weed only in a small part of its adventive range. This is why control requires an integrated strategy where various options are used in combination in order to enhance suppression or elimination.

An issue that has not been addressed adequately is the cost-effectiveness of various control options. This need has led to a number of recent studies, mainly undertaken in South Africa, to determine if the benefits of invasive plant control outweigh the costs. For example, under a dynamic simulation of an ecological-economic model of IAP control in a mountain fynbos ecosystem in South Africa, it was found that the cost of proactive clearing would range from $0.6 \%$ to $4.76 \%$ of the economic value of ecosystem services, while resulting in an increase of the value of these services between 138 and $149 \%$ [177]. Also in South Africa, De Lange \& van Wilgen [164] estimated the value of ecosystem services at ZAR 152 billion (presently, about US\$ 11.551 billion) annually, of which an estimated ZAR 6.5 billion (US\$ 490 million) is lost every year due to IAPs. However, the loss would have been an estimated additional ZAR 41.7 billion (US\$3169 million) had no invasive plant control been carried out. Costs of aquatic weed control in Florida in the late 1960 s were estimated to be US\$ 6 million annually and benefits were reported as US\$ 82 million, with the largest benefits coming from increased land use (due to drainage) and prevented flood damage [178].

Studies on the benefits of targeting individual species also have provided evidence of cost effectiveness. An analysis of the costs and benefits of the invasive Australian tree Acacia mearnsii De Wild. (Fabaceae) in South Africa suggests that a 'do nothing' scenario (with no attempts to control the spread of the species beyond the limits of commercial plantations) is not cost-effective, as the benefit: cost ratio is around 0.4 [179]. The most attractive control option will be a combination of biological control of the whole plant (flowers, seed pods, leaves and stems) and physical clearing (benefit: cost ratio of 7.5) [179]. Brown \& Daigneault [180] found that an integrated approach to the control of the invasive tree Spathodea campanulata Beauv. (Bignoniaceae) in Fiji derived monetized benefits of US\$ 3.7 for each US\$ 1 spent, even without explicitly considering biodiversity, culture, and other non-monetized benefits of control. It is estimated that tamarisk (Tamarix spp.; Tamaricaceae) invasions in the western United States cost about US\$ 280-450 ha $\mathrm{ha}^{-1}$ [181]. Eradicating these invasive species and restoring native riparian communities throughout the region would cost about US\$ 7400 ha
${ }^{-1}$, considerably more than the current costs of impacts. However, these intervention costs would be fully recovered in as few as 17 years, after which the societal, ecological, and economic benefits of restoration would continue to accrue indefinitely [182].

Although there have been comparatively few studies to evaluate the overall costs and benefits of an integrated control strategy, the benefits of classical biological control programmes have been well documented. An analysis of some biocontrol research programmes in South Africa found that benefit: cost ratios ranged from 34:1 for Lantana camara L. (Verbenaceae) to 4331:1 for golden wattle, Acacia pycnantha Benth. (Fabaceae) [183]. In fact, the benefit: cost ratios for biocontrol projects in South Africa range from 50:1 for invasive sub-tropical shrubs to 3726:1 for invasive Australian trees (de Lange and van Wilgen, 2010 [164]). It is also estimated that biological control agents present in South Africa have reduced the financial costs of mechanical and chemical control by more than $19.8 \%$, or ZAR 1.38 billion (presently, about US\$ 104.8 million) [184]. It is further estimated that biological control programmes, if fully implemented in the future, may reduce control costs by an additional 41.4\%, or ZAR 2.89 billion (presently, about US\$ 219.5 million) [184]. These findings are supported by studies in Australia, which have found that every dollar invested in the invasive plant biological control effort yielded a return of $\mathrm{A} \$$ 23.10 [185]. There, the benefit: cost ratio for agriculture alone (in terms of both cost savings on control and increased production) was 17.4. If current annual expenditures on biological control research continue into the future, it is expected that projects targeting invasive plants with biological control agents in Australia may provide, on average, an annual net benefit of A\$ 95.3 million, of which A $\$ 71.8$ million is expected to flow into the agriculture sector [185]. A good example of the benefits of biological control is that of water hyacinth in southern Benin, where the reduction of this aquatic plant by biological control has been credited with an increase in income of US\$30.5 million per year to a community of about 200,000 people [186]. If one assumes that the benefits stay constant over the next 20 years, the accumulated present value will be US\$ 260 million - a benefit: cost ratio of 124:1 [186].

In summary, the most cost-effective way of controlling invasive plants is by combining two or more of the methods mentioned above. For example, manual control used in combination with chemical and/or biological control, commonly known as integrated pest management (IPM), should be implemented wherever possible in order to reduce costs and improve the efficacy of control across a landscape. Invasive plants can be effectively 
controlled over large areas by developing and implementing an integrated management strategy.

\section{The potential effect of invasive alien plant management on the incidence of malaria}

If in certain regions IAPs are exacerbating malaria transmission, it would be useful to know what will occur if the distribution and densities of these weeds are reduced. For certain scenarios this appears straightforward. If the invasion of alien plants leads to increased poverty by reducing crop yields and pasture productivity, then improving people's socio-economic conditions should, to an extent, help them escape the poverty trap of malaria by providing increased access to medication and preventive measures. In arid areas where an IAP might have expanded the range of a malaria vector, removal of the weed would likely reverse this expansion [35]. A similar argument would hold for cases where an invasive plant might prolong the seasonal population peaks of vectors. Support for the latter notion comes from a recent field trial in Mali, where the impact of the invasive shrub Prosopis juliflora on malaria mosquitoes was investigated during the dry season [35]. Villages without the plant were compared to those where $P$. juliflora had become established. In half of the latter villages, at a certain point all flowering branches of this plant were removed. Anopheles spp. were monitored throughout, to examine whether removal of this invasive putative nectar source affected mosquito species composition, age structure, population size, and sugar-feeding status. The average number of female Anopheles caught per trap declined more than two-fold in the villages where inflorescences had been removed, while numbers stayed stable in the positive and negative control villages. Likewise, the proportion of females that survived for at least 3 gonotrophic cycles dropped from $35 \%$ to $11 \%$. Sugar-feeding rates also dropped dramatically following removal of the flowering branches. These results are similar to those of a study that indicated that in areas with more abundant or richer nectar sources, Anopheles spp., mosquitoes would live longer and greater populations would be sustained [64]. Another notable result was that the species composition shifted from a mix of An. coluzzi, An. gambiae and An. arabiensis to one dominated by An. coluzzi. Whether this species shift toward $A n$. coluzzi reflects its lower dependence on nectar, or perhaps a tendency to make use of other sources available in arid environments (for instance, by piercing plant tissues), remains to be investigated. It also will be important to investigate the impacts of (i) invasive plants on mosquitoes throughout the year, not just in the dry season; (ii) other IAP species (both terrestrial and aquatic), to determine whether these effects are mosquito-plant species-specific or instead applicable to invasive species and mosquitoes in general; and (iii) invasive plants in a wider range of habitats, particularly in more verdant areas where mosquito-plant interactions will be far more complex. Another recent invasive plant-removal experiment performed in North America suggests that at least some of these aspects may be common. In a 2-year study using a Before-After/Control-Impact design, [187] found that the abundance of Culex spp. declined following removal of invasive Amur honeysuckle (Lonicera maacki). Although they did not measure vector survival rates directly, they did find a more favourable microclimate for mosquitoes in areas with honeysuckle. Neither study evaluated the impact on pathogen transmission, but it could be considerable. A quick calculation shows that in the case of $P$. juliflora inflorescence removal, assuming that only vector mortality and abundance would change by the levels indicated in the paper [35], and assuming a gonotrophic cycle length of 3 days and an extrinsic incubation period of 12 days, $R_{0}$ would be reduced by a factor of approximately 28. However, as reviewed above, many of the other behavioural and life history traits of mosquitoes also may change with changes in vegetation, and it will be important to study such impacts in a comprehensive manner in future experiments.

Less clear is what happens if an invasive plant merely replaces part of the local plant community and (perhaps) increases the available plant biomass and nectar in that region. There are several important questions that cannot in an obvious way be extrapolated from the laboratory and semi-field experiments that have been done to date. The initial questions are these: Which plants tend to be replaced in invaded landscapes, those that already provide nectar to mosquitoes, or those that are poor nectar-hosts or relatively unattractive to mosquitoes? And by how much does the availability of nectar change in the landscape, whether as a result of different nectar production rates, or changes in the invertebrate community within the landscape? If there is generally an increase in the availability of nectar, how does this affect mosquito nectar-feeding, human-biting behaviour, reproductive success, and population size throughout the year? It is worth noting that in most studies there were only two levels of nectar abundance, high and low, or present and absent. To understand how invasive plants might affect vectorial capacity, we would require insights into mosquito traits as a function of nectar availability. For instance, it is likely that there is a lower limit of nectar availability at which mosquito populations can be sustained [73], but whether that lower level is ever relevant in nature, i.e. 
whether nectar ever becomes limiting in nature, remains unknown [30]. Likewise, above a certain level of nectar abundance, further increases may have limited impact on mosquitoes. An additional complication is that nectar feeding appears to be more relevant to energetically-deprived or smaller mosquitoes, and when blood hosts are inaccessible or absent $[68,188]$. It is possible that this interaction with blood-host accessibility or presence explains why in some circumstances where sugar access is greater, the biting rate and resulting vectorial capacity of the mosquito population is lower $[50,66]$. Thus, ideally we would need to measure mosquito traits as a function of nectar abundance at different levels of blood-host presence.

In practical terms, another point of uncertainty relates to the intensity of transmission that occurs in a given region. In areas where vectorial capacity or $R_{0}$ (or alternatively, the proportion of humans that are parasitemic) is very high, a strong reduction in vectorial capacity and therefore $R_{0}$, may still have little impact on malaria prevalence. It is only in areas with a lower transmission pressure that reductions in vectorial capacity will have a more pronounced impact on malaria incidence. This suggests that if management of nectar sources of mosquitoes has a strong impact on vectorial capacity, it could potentially contribute in a significant way to malaria control in areas of low transmission. Alternatively, plant removal could be considered as one of many components of an integrated control strategy in high transmission areas. This might be particularly relevant in areas where use of long-lasting insecticidal nets and human-case management are insufficient to interrupt transmission, or areas where insecticide resistance is climbing.

The relationship between many Anopheles species and aquatic IAPs is often strong enough to warrant invasive plant control as an additional malaria management tool. The same can be said for many mosquito species and other disease vectors. We must ask ourselves if manipulating the environment to control any given malaria vector includes the risk of creating suitable environments for other malaria vectors or vectors of other diseases. The current evidence suggests this would not be the case: removal of emergent vegetation to control An. funestus, for instance, would not necessarily create more good habitats for An. gambiae (s.l.) and other vectors, inasmuch as large bodies of exposed, deep, clear water are unsuitable for oviposition and larval development of mosquitoes in general [75, 76, 78, 88-90]. Added to the economic and environmental benefits of applying biological control for aquatic weeds, it is apparent that malaria suppression also could profit from aquatic invasive plant management, which already has had successes.

\section{Conclusions}

This review highlights the complexity of the Anophelesplant relationship and the necessity of understanding it, in order to anticipate how and when IAPs may increase malaria incidence. By using our knowledge of the interplay of factors influencing this relationship from the pathogen's perspective, it appears we can judiciously apply invasive-plant interventions to suppress malaria transmission, or even to interrupt it altogether in some instances. Field experiments focused on unknown features of the mosquito-plant interface will yield more information needed to know best how to approach the invasive-plant problem. Initial investigations should use the entomological inoculation rate (EIR) to compare malaria exposure in areas with similar housing conditions, human density, socioeconomics, and bed-net usage, leaving only alien-plant establishment as the variable. If the comparison indicates a strong impact of these plants on Plasmodium exposure, further studies on mosquito foraging behaviour and its implications for population dynamics and vectorial capacity will be revealing and provide further insights. These will inform how IAP management can contribute to malaria control and ensure that programmes targeting different aspects of environmental and human health are to be coordinated in a beneficial manner.

\section{Abbreviations \\ $C$ : Vectorial capacity; EIR: Entomological inoculation rate; $N_{h}$ : Population size of humans; $N_{v}$ : Population size of vectors; $R_{0}$ : Basic reproduction number of malaria; ZAR: South African rand}

\section{Acknowledgements}

Many of the ideas elaborated on in this review were informed by and initially developed during group discussions at a workshop held in Naivasha, Kenya, in December of 2015. We are grateful to all the participants for sharing their expertise and insights: Christian Borgemeister, Alexandra Chaskopoulou, Susan Imbahale, Samson Kiware, Dhileepan Kunjithapatham, Theo Linders, Charles Mbogo, Günter Müller, James Mutunga, Ephantus Muturi, Patricia Neenan, Vincent Nyasembe, Erik Ochomo, Bernie Roitberg, Dan Strickman, Zain Syed, David Tchouassi, Baldwyn Torto, James Tumlinson, Holly Tuten, Winnie Nunda, Andrew Wannenburgh, and Rue-De Xue. Funding for the workshop was provided by the Bill \& Melinda Gates Foundation and $C A B I$.

\section{Funding}

This work was supported by the Bill and Melinda Gates Foundation (grant number OPP1135160)

\section{Availability of data and materials} Not applicable.

\section{Authors' contributions}

STM and CS led on Introduction. CS, GCW and WAF led on section "Do invasive alien plants have a positive influence on the rate of malaria transmission?". AW, STM and GCW led on "The potential for invasive alien plants to be managed on a large scale". All authors contributed to the synthesis of the last sections. All authors read and approved the final manuscript.

Ethics approval and consent to participate Not applicable. 


\section{Consent for publication}

Not applicable.

\section{Competing interests}

The authors declare that they have no competing interests.

\section{Publisher's Note}

Springer Nature remains neutral with regard to jurisdictional claims in published maps and institutional affiliations.

\section{Author details}

${ }^{1}$ Illinois Natural History Survey, University of Illinois, Urbana, Champaign, IL 61820, USA. ${ }^{2}$ CABI Africa, 673 Limuru Road, Muthaiga, PO Box 633-00621, Nairobi, Kenya. ${ }^{3}$ Fundación para el Estudio de Especies Invasivas (FuEDEI), Bolivar 1559, Hurlingham, Buenos Aires, Argentina. ${ }^{4}$ Department of Evolution, Ecology and Organismal Biology, Ohio State University, Columbus, $\mathrm{OH} 43210$, USA. ${ }^{5} \mathrm{CABI}$, Bakeham Lane, Egham, Surrey TW20 9TY, UK

\section{Received: 2 November 2017 Accepted: 12 January 2018}

\section{Published online: 01 February 2018}

\section{References}

1. World Health Organisation. World Malaria Report. http://www.who.int/ malaria/publications/world_malaria_report_2014/report/en/. Accessed 13 Dec 2016.

2. Raghavendra K, Barik TK, Niranjan Reddy BP, Sharm P, Dash AP. Malaria vector control: from past to future. Parasitol Res. 2011;108:757-79.

3. Bhatt S, Weiss DJ, Cameron E, Bisanzio D, Mappin B, Darymple U, et al. the effect of malaria control on Plasmodium falciparum in Africa between 2000 and 2016. Nature. 2015;526:207-11.

4. CJL M, Ortblad KF, Guinovart C, Lim SS, Wolock TM, Roberts DA, et al Global, regional and national incidence and mortality for HIV, tuberculosis, and malaria during 1990-2013: a systematic analysis for the global burden of disease study 2013. Lancet. 2014;384(9947):1005-70.

5. Curtis C, Maxwell C, Lemnge M, Kilama WL, Steketee RW, Hawley WA, et al. Scaling-up coverage with insecticide-treated nets against malaria in Africa: who should pay? Lancet Infect Dis. 2003:3:304-7.

6. Ranson H, N'Guessan R, Lines J, Moiroux N, Nkuni Z, Corbel V. Pyrethroid resistance in African anopheline mosquitoes: what are the implications for malaria control? Trends Parasitol. 2011;27:91-8.

7. Roberts DR, Andre RG. Insecticide resistance issues in vector-borne disease control. Am J Trop Med Hyg. 1994;50:21-34

8. Overgaard HJ, Sandve SR, Suwonkerd W. Evidence of anopheline mosquito resistance to agrochemicals in northern Thailand. SEA J Trop Med Pub Health. 2005;36(Suppl. 4):152-7.

9. Nkya TE, Akhouayri I, Poupardin R, Batengana B, Mosha F, Magesa S, et al. Insecticide resistance mechanisms associated with different environments in the malaria vector Anopheles gambiae: a case study in Tanzania. Malaria J. 2014;13:28.

10. Relyea RA. The impact of insecticides and herbicides on the biodiversity and productivity of aquatic communities. Ecol Appl. 2005;15:618-27.

11. Fillinger U, Ndenga B, Githeko A, Lindsay SW. Integrated malaria vector control with microbial larvicides and insecticide-treated nets in western Kenya: a controlled trial. Bull World Health Organ. 2009;87:655-65.

12. Kroeger I, Liess M, Dziock F, Duquesne S. Sustainable control of mosquito larvae in the field by the combined actions of the biological insecticide Bti and natural competitors. Vector Ecol. 2013;38:82-9.

13. Reiskind M, Zarrabi A, Lounibos L. Invasive leaf resources alleviate density dependence in the invasive mosquito, Aedes albopictus. Biol Inv. 2010; 12:2319-28.

14. Mack R, Smith M. Invasive plants as catalysts for the spread of human parasites. NeoBiota. 2011;9:13-29.

15. Nash TAM. Africa's bane: the tsetse fly. London: Collins; 1969

16. Syed Z, Guerin PM. Tsetse flies are attracted to the invasive plant Lantana camara. J Insect Physiol. 2004;50:43-50.

17. Allan BF, Dutra HP, Goessling LS, Barnett K, Chase JM, Marquis RJ, et al. Invasive honeysuckle eradication reduces tick-borne disease risk by altering host dynamics. Proc Natl Acad Sci USA. 2010;107:18523-7.

18. Civitello DJ, Cohen J, Fatima H, Halstead N, Liriano J, McMahon TA, et al. Biodiversity inhibits parasites: broad evidence for the dilution effect. Proc Natl Acad Sci USA. 2015;112:8667-71.
19. Mwangi E, Swallow B. Prosopis juliflora invasion and rural livelihoods in the Lake Baringo area of Kenya. Conserv Soc. 2008:6:130-40.

20. Van Wilgen BW, Reyers B, Le Maitre DC, Richardson DM, Schonegevel L. A biome-sale assessment of the impact of invasive alien plants on ecosystem species in South Africa. J Environ Manag. 2008;89:336-49.

21. Maundu P, Kibet S, Morimoto Y, Imbumi M, Adekar R. Impact of Prosopis juliflora on Kenya's semi-arid and arid ecosystems and local livelihoods. Biodiversity. 2009;10:33-50.

22. Pratt CF, Constantine KL, Murphy ST. Economic impacts of invasive alien species on African smallholder livelihoods. Glob Food Secur. 2017;14:31-7.

23. Shackleton RT, Witt ABR, Nunda W, Richardson DM. Chromolaena odorata (Siam weed) in eastern Africa: distribution and socio-ecological impacts. Biol Inv. 2017:19:1285-98.

24. Shackleton RT, ABR W, Aool W, Pratt C. Distribution of the invasive alien weed, Lantana camara, and its ecological and livelihood impacts in eastern Africa. Afr J Range Forage Sci. 2017;34:1-11.

25. Shackleton RT, Witt ABR, Piroris FM, van Wilgen BW. A survey of the distribution and perceptions of the socio-economic and ecological impacts of the invasive alien cactus Opuntia stricta in East Africa. Biol Inv. 2017;19(8):2427-41

26. Vila M, Pujadas J. Land-use and socio-economic correlates of plant invasions in European and north African countries. Biol Conserv. 2001;100:397-401.

27. Vila M, Espinar J, Hejda M, Hulme P, Jarosik V, Maron J, et al. Ecological impacts of invasive alien plants: a meta-analysis of their effects on species, communities and ecosystems. Ecol Lett. 2011;14:702-8.

28. Hellmann JJ, Byers JE, Bierwagen BG, Dukes JS. Five potential consequences of climate change for invasive species. Conserv Biol. 2008;22:534-43.

29. Bezeng BS, Morales-Castilla I, van der Bank M, Yessoufou K, Daru BH, Davies TJ. Climate change may reduce the spread of non-native species. Ecosphere. 2017:e01694

30. Foster WA. Mosquito sugar feeding and reproductive energetics. Annu Rev Entomol. 1995:40:443-74

31. Manda H, Gouagna LC, Nyandat E, Kabiru EW, Jackson RR, Foster WA, et al. Discriminative feeding behaviour of Anopheles gambiae s.s. On endemic plants in western Kenya. Med Vet Entomol. 2007;21:103-11.

32. Müller GC, Beier JC, Traore SF, Toure MB, Traore MM, Bah S, et al. Field experiments of Anopheles gambiae attraction to local fruits/seedpods and flowering plants in Mali to optimize strategies for malaria vector control in Africa using attractive toxic sugar bait methods. Malaria J. 2010;9(1):262.

33. Rajnikant BRM, Sharma RC, Gupta DK, Gautam AS. Anopheline breeding in ponds of central Gujarat with reference to water hyacinth infestation. Ind J Malariol. 1992;29:57-61.

34. Webb CE, Ironside A, Mansfield S. A comparison of oviposition preference in the presence of three aquatic plants by the mosquitoes Culex annulirostris Skuse and Culex quinquefasciatus (Culicidae: Diptera) in laboratory tests. Gen App Entomol. 2012:41:21-6.

35. Müller GC, Junnila A, Traore M, Traore SF, Doumbia S, Sissoko F, et al. The invasive shrub Prosopis juliflora enhances the malaria parasite transmission capacity of Anopheles mosquitoes: a habitat manipulation experiment. Malaria J. 2017;16(237)

36. Diekmann O, Heesterbeek JAP. Mathematical epidemiology of infectious diseases: model building, analysis and interpretation (Vol. 5). Chichester: John Wiley \& Sons; 2000.

37. Smith D, McKenzie E. Statics and dynamics of malaria infection in Anopheles mosquitoes. Malaria J. 2004:3:13.

38. Garrett-Jones C. Prognosis for interruption of malaria transmission through assessment of the mosquito's vectorial capacity. Nature. 1964;204:1173-5.

39. Stone CM, Foster WA. Ecology of parasite-vector interactions. In: Takken W, CJM K, editors. Plant-sugar feeding and vectorial capacity. Wageningen: Wageningen Academic Publishers; 2013. p. 35-79.

40. Zhu L, Marshall JM, Qualls WA, Schlein Y, McManus JW, Arheart KL, et al. Modelling optimum use of attractive toxic sugar bait stations for effective malaria vector control in Africa. Malaria J. 2015;14(492)

41. Spielman A. Bionomics of autogenous mosquitoes. Annu Rev Entomol. $1971 ; 16: 231-48$

42. Nyasembe VO, Teal PEA, Mukabana WR, Tumlinson JH, Torto B. Behavioural response of the malaria vector Anopheles gambiae to host plant volatiles and synthetic blends. Parasit Vectors. 2012;5:234

43. Nayar JK, Sauerman DM. Physiological effects of carbohydrates on survival, metabolism, and flight potential of female Aedes taeniorhynchus. J Insect Physiol. 1971;17:2221-33. 
44. Van Handel E. Metabolism of nutrients in the adult mosquito. Mosq News. 1984;44:573-9.

45. Takken W, Verhulst NO. Host preferences of blood-feeding mosquitoes. Annu Rev Entomol. 2013;58:433-53.

46. George J, Blanford H, Thomas MB, Baker TC. Malaria mosquitoes host-locate and feed upon caterpillars. PLoS One. 2014;9(11):e108894.

47. Harrington LC, Edman JD, Scott TW. Why do female Aedes aegypti (Diptera: Culicidae) feed preferentially and frequently on human blood? J Med Entomol. 2001;38:411-22.

48. Foster WA, Takken W. Nectar-related vs. human-related volatiles: behavioural response and choice by female and male Anopheles gambiae (Diptera: Culicidae) between emergence and first feeding. Bull Entomol Res. 2004;94:145-57.

49. Gary RE, Foster WA. Diel timing and frequency of sugar feeding in the mosquito Anopheles gambiae, depending on sex, gonotrophic state and resource availability. Med Vet Entomol. 2006;20:308-16.

50. Stone CM, Jackson BT, Foster WA. Effects of bed net use, female size, and plant abundance on the first meal choice (blood vs sugar) of the malaria mosquito Anopheles gambiae. Malaria J. 2012;11:3.

51. Impoinvil DE, Kongere JO, Foster WA, Njiru BN, Killeen GF, Githure J, et al. Feeding and survival of the malaria vector Anopheles gambiae on plants growing in Kenya. Med Vet Entomol. 2004;18:108-15.

52. Gouagna LC, Poueme RS, Dabiré KR, Ouédraogo JB, Fontenille D, Simard F. Patterns of sugar feeding and host plant preferences in adult males of An. gambiae (Diptera: Culicidae). J Vector Ecol. 2010;35:267-76.

53. Nikbakhtzadeh MR, Terbot JW II, Otienoburu PE, Foster WA. Olfactory basis of floral preference of the malaria vector Anopheles gambiae (Diptera: Culicidae) among common African plants. J Vector Ecol. 2014;39:372-83.

54. Manda H, Gouagna LC, Foster WA, Jackson RR, Beier JC, Githure I, Hassanali A. Effect of discriminative plant-sugar feeding on the survival and fecundity of Anopheles gambiae. Malaria J. 2007;6:113.

55. Mng'ong'o FC, Sambali JJ, Sabas E, Rubanga J, Magoma J, Ntamatungiro AJ, et al. Repellent plants provide affordable natural screening to prevent mosquito house entry in tropical rural settings-results from a pilot efficacy study. PLoS One. 2011;6(10):e25927.

56. Curry DP. Breeding of Anopheline mosquitoes among aquatic vegetation of Gatun Lake, accompanied by periodic long flights of $A$. albimanus Wied. Sth Med J. 1934:27:644-51

57. Rozeboom LE. A symposium on human malaria: with special reference to North America and the Caribbean region. In: Moulton FR, editor. Distribution and ecology of the Anopheles mosquitoes of the Caribbean region. USA: American association for the Advancement of Science; 1941. p. 98-107.

58. Meyer SL. Plants of importance in the breeding of Anopheles albimanus Wied. in Panama. Bull Torrey Bot Club. 1947;74:257-61.

59. Soper FL, Wilson DB. Anopheles gambiae in Brazil: 1930 to 1940. New York: Rockefeller Foundation; 1943

60. Killeen GF, Fillinger U, Kiche I, Gouagna LC, Knols BGJ. Eradication of Anopheles gambiae from Brazil: lessons for malaria control in Africa? Lancet Infect Dis. 2002;2:618-27.

61. Morrison AC, Zielinski-Gutierrez E, Scott TW, Rosenberg R. Defining challenges and proposing solutions for control of the virus vector Aedes aegypti. PLoS Med. 2008:5(3):e68.

62. Walker K, Lynch M. Contributions of Anopheles larval control to malaria suppression in tropical Africa: review of achievements and potential. Med Vet Entomol. 2007;21:2-21.

63. Gary RE, Foster WA. Anopheles gambiae feeding and survival on honeydew and extra-floral nectar of peridomestic plants. Med Vet Entomol. 2004;18:102-7.

64. Gu W, Müller G, Schlein Y, Novak RJ, Beier JC. Natural plant sugar sources of Anopheles mosquitoes strongly impact malaria transmission potential. PLoS One. 2001;6(1):e15996.

65. Straif SC, Beier JC. Effects of sugar availability on the blood feeding behaviour of Anopheles gambiae (Diptera: Culicidae). J Med Entomol. 1996; 33:608-12.

66. Gary RE, Foster WA. Effects of available sugar on the reproductive fitness and vectorial capacity of the malaria vector Anopheles gambiae (Diptera: Culicidae). J Med Entomol. 2001;38:22-8.

67. Ebrahimi B, Jackson BT, Guseman JL, Przybylowicz CM, Stone CM, Foster WA. Alteration of plant species assemblages can decrease the transmission potential of malaria mosquitoes. J Appl Ecol. 2017, 2017; doi.org/10.1111/ 1365-2664.13001
68. Stone CM, Jackson BT, Foster WA. Effects of plant-community composition on the vectorial capacity and fitness of the malaria mosquito Anopheles gambiae. Am J Trop Med Hygiene. 2012;87:727-36.

69. Hien D, Dabiré K, Roche B, Diabaté A, Yerbanga RS, Cohuet A, et al. Plantmediated effects on mosquito capacity to transmit human malaria. PLoS Pathog. 2016;12(8):e1005773.

70. Gary RE, Cannon JW, Foster WA. Effect of sugar on male Anopheles gambiae Giles (Diptera: Culicidae) mating performance, as modified by temperature, space, and body size. Parasit Vectors. 2009;2:19.

71. Stone CM, Taylor RM, Roitberg BD, Foster WA. Sugar deprivation reduces insemination of Anopheles gambiae (Diptera: Culicidae), despite daily recruitment of adults, and predicts decline in model populations. J Med Entomol. 2009;46:1327-37.

72. Barber MA, Hayne TE. Water hyacinth and the breeding of Anopheles. Pub Health Rep (1896-1970). 1925;40:2557-62

73. Chinery WA. Effects of ecological changes on the malaria vectors Anopheles funestus and the Anopheles gambiae complex of mosquitoes in Accra, Ghana. J Trop Med Hygiene. 1984;87:75-81.

74. Sattler MA, Mtasiwa D, Kiama M, Premji Z, Tanner M, Killeen GF, et al. Habitat characterization and spatial distribution of Anopheles sp. mosquito larvae in Dar es Salaam (Tanzania) during an extended dry period. Malaria J. 2005;4(4)

75. Sinka ME, Rubio-Palis Y, Manguin S, Patil AP, Temperley WH, Gething PW, et al. The dominant Anopheles vectors of human malaria in the Americas: occurrence data, distribution maps and bionomic précis. Parasit Vectors. 2010;3:72.

76. Sinka ME, Bangs MJ, Manguin S, Coetzee M, Mbogo CM, Hemingway J, et al The dominant Anopheles vectors of human malaria in Africa, Europe and the Middle East: occurrence data, distribution maps and bionomic précis. Parasit Vectors. 2010;3:117.

77. Dia I, Guelbeogo MW, Ayala D. Chapter 7. Advances and perspectives in the study of the malaria mosquito Anopheles funestus. In: Manguin S, editor. Anopheles mosquitoes - New insights into malaria vectors. InTech; 2013. doi: https://doi.org/10.5772/55389.

78. Adoka SO, Dida G, Anyona DN, Matano AS, Othero DA, Kanangire CK. Spatial distribution and habitat characterisation of mosquito species in the lake and land habitats of western Kenya. East Afr Med J. 2016;93:117-26.

79. Zetek J. Anopheles breeding among water lettuce - a new habitat. Bull Entomol Res. 1920;11:73-5.

80. Curry DP. Some observations on the Nyssorhynchus group of the Anopheles (Culicidae) of Panama. Am J Hygiene. 1932;15:566-72.

81. Eyles DE, Robertson JL Jr. A Guide and key to the aquatic plants of the southeastern United States. Pub Health Bull. 1944;286:1-141.

82. Alarcón-Elbal PM. Plantas invasoras acuáticas y culícidos: un binomio peligroso. Invasive aquatic plants and culicids: a dangerous duo. Bol Real Soc Española Hist Nat. Sección Biología. 2013;107:5-15.

83. Orr B, Resh V. Influence of Myriophyllum aquaticum cover on Anopheles mosquito abundance, oviposition, and larval microhabitat. Oecologia. 1992;90:474-82.

84. Srivastava RK, Srivastava H. Observations on anopheline breeding in relation to aquatic plants in different breeding habitats of Kheda (Gujarat). J Comm Dis. 2004;36:187-94.

85. Rejmánková E, Roberts D, Pawley A, Manguin S, Polanco J. Predictions of adult Anopheles albimanus densities in villages based on distances to remotely sensed larval habitats. Am J Trop Med Hygiene. 1995;53:482-8.

86. Rejmánková E, Savage HM, Rejmánek M, Arredondo-Jiménez Jl, Roberts DR. Multivariate analysis of relationships between habitats, environmental factors and occurrence of Anopheline mosquito larvae Anopheles albimanus and A. preudopunctipennis in southern Chiapas, Mexico. J Appl Ecol. 1991;28:827-41.

87. Rejmánková E, Roberts DR, Harbach RE, Pecor J, Peyton EL, Manguin S, et al. Environmental and regional determinants of Anopheles (Diptera: Culicidae) larval distribution in Belize, central America. Environ Entomol. 1993:22:978-92.

88. Almirón WR, Brewer ME. Classification of immature stage habitats of Culicidae (Diptera) collected in Córdoba, Argentina. Mem Instituto Oswaldo Cruz. 1996;91:1-9.

89. Stein M, Ludueña-Almeida F, Willener JA, Almirón WR. Classification of immature mosquito species according to characteristics of the larval habitat in the subtropical province of Chaco, Argentina. Mem Instit Oswaldo Cruz. 2011;106:400-7. 
90. Savage HM, Rejmánková E, Arredondo-Jiménez Jl, Roberts DR, Rodríguez $\mathrm{MH}$. Limnological and botanical characterization of larval habitats for two primary malarial vectors, Anopheles albimanus and Anopheles pseudopunctipennis, in coastal areas of Chiapas state. Mexico J Am Mosa Cont Assoc. 1990;6:612-20.

91. Sinka ME, Bangs MJ, Manquin S, Chareonviriyaphap T, Patil AP, Temperley $\mathrm{WH}$, et al. The dominant Anopheles vectors of human malaria in the AsiaPacific region: occurrence data, distribution maps and bionomic précis. Parasit Vectors. 2011;4:89.

92. Matheson R. The utilization of aquatic plants as aids in mosquito control. Am Nat. 1930;64:56-86.

93. Hobbs JH, Molina PA. The influence of the aquatic fern Salvinia auriculata on the breeding of Anopheles albimanus in coastal Guatemala. Mosq News. 1983:43:456-9

94. Imbahale SS, Mweresa CK, Takken W, Mukabana WR. Development of environmental tools for anopheline larval control. Parasit Vectors. 2011;10(1): 184.

95. Amerasinghe FP, Kulasooriya SA. Azolla vs mosquitoes: some experiments with Culex quinquefasciatus. MIRCEN J App Microbiol Biotechnol. 1985;1: 355-63.

96. Greenway M, Dale P, Chapman H. An Assessment of mosquito breeding and control in 4 surface flow wetlands in tropical-subtropical Australia. Water Sci Technol. 2003;48:249-56.

97. Furlow BM, Hays KL. Some influences of aquatic vegetation on the species and number of Culicidae (Diptera) in small pools of water. Mosq News. 1972;32:595-9.

98. Mwingira VS, Mayala BK, Senkoro KP, Rumisha SF, Shayo EH, Mlozi MR, et al. Mosquito larval productivity in rice-fields infested with Azolla in Mvomero District, Tanzania. Tanzania J Health Res. 2009;11:17-22.

99. Rajendran R, Reuben R. Evaluation of the water fern Azolla microphylla for mosquito population management in the rice-land agro-ecosystem of south India. Med Vet Entomol. 1991;5:299-310.

100. Hoyer MV, Canfield DE. Aquatic macrophytes and their relation to fish populations of Florida lakes. Charleston, South Carolina: Abstracts, Thirtythird Annual Meeting, The Aquatic Plant Management Society, Inc., and The Fifteenth Annual Meeting, The South Carolina Aquatic Plant Management Society, Inc; 1993.

101. Bennett FD. Investigations On the insects attacking the aquatic ferns Salvinia spp. in Trinidad and northern South America. In: Proceedings of the Nineteenth Annual Meeting Southern Weed Conference. USA: Southern Weed Society. 1966;497-504.

102. Thomas PA, Room PMT. Control of Salvinia molesta. Nature. 1996;320:581-4.

103. Orr BK, Resh VH. Experimental Test of the influence of aquatic macrophyte cover on the survival of Anopheles larvae. J Am Mosq Control Assoc. 1989:5:579-85.

104. Bond JG, Rojas JC, Arredondo-Jiménez Jl, Quiroz-Martínez H, Valle J, Williams T. Population control of the malaria vector Anopheles pseudopunctipennis by habitat manipulation. Proc Royal Soc London B. 2004;271:2161-9.

105. Bond JG, Quiroz-Martínez H, Rojas JC, Valle J, Ulloa A, Williams T. Impact of environmental manipulation for Anopheles pseudopunctipennis Theobald control on aquatic insect communities in southern Mexico. J Vector Ecol. 2007:32:41-53.

106. Bradley GH. Some factors associated with the breeding of Anopheles mosquitoes. J Agric Res. 1932;44:381-99.

107. Orr BK, Resh VH. Interactions among mosquitofish (Gambusia affinis), sago pondweed (Potamogeton pectinatus), and the survivorship of Anopheles mosquito larvae. In: Proceedings and Papers of the 55th Annual Conference California Mosquito and Vector Control Association. Sacramento; 1987. p. 94-7

108. Minakawa N, Seda P, Yan G. Influence of host and larval habitat distribution on the abundance of African malaria vectors in western Kenya. Am J Trop Med Hygiene. 2002;67:32-8.

109. Rubio-Palis Y, Menare C, Quinto A, Magris M, Amarista M. Caracterización de criaderos de anofelinos (Diptera: Culicidae) vectores de malaria del Alto Orinoco, Amazonas, Venezuela. Entomotropica. 2005;20:29-38.

110. Dukeen M, Omer S. Ecology of the malaria vector Anopheles arabiensis Patton (Diptera: Culicidae) by the Nile in northern Sudan. Bull Entomol Res. 1986;76:451-67.

111. Davis T, Kline D, Kaufman P. Aedes albopictus (Diptera: Culicidae) oviposition preference as influenced by container size and Buddleja davidii plants. J Med Entomol. 2016;53:273-8.
112. Huang J, Walker E, Otienoburu P, Amimo F, Vulule J, Miller J. Laboratory tests of oviposition by the African malaria mosquito, Anopheles gambiae, on dark soil as influenced by presence or absence of vegetation. Malaria J. 2006;5:88.

113. Overgaard $H$. Effect of plant structure on oviposition behavior of Anopheles minimus s.l. J Vector Ecol. 2007:32:193-7.

114. Fillinger U, Sombroek H, Majambere S, van Loon E, Takken W, Lindsay S. Identifying the most productive breeding sites for malaria mosquitoes in Gambia. Malaria J. 2009:8:62

115. Hackett LW, Russell PF, Scharff JW, Senior WR. The present use of naturalistic measures in the control of malaria. Bull Health Organ. 1938;7:1016-64.

116. Ye-Ebiyo Y, Pollack R, Spielman A. Enhanced development in nature of larval Anopheles arabiensis mosquitoes feeding on maize pollen. Am J Trop Med Hygiene. 2000;63:90-3.

117. Ye-Ebiyo Y, Pollack R, Kiszewski A, Spielman A. Enhancement of development of larval Anopheles arabiensis by proximity to flowering maize (Zea mays) in turbid water and when crowded. Am J Trop Med Hygiene. 2003;68:748-52.

118. Muturi EJ, Gardner AM, Bara JJ. Impact of an alien invasive shrub on ecology of native and alien invasive mosquito species (Diptera: Culicidae). Environ Entomol. 2015:44:1308-15.

119. Gardner AM, Allan BF, Frisbie LA, Muturi EJ. Asymmetric effects of native and exotic invasive shrubs on ecology of the West Nile virus vector Culex pipiens (Diptera: Culicidae). Parasit Vectors. 2015;8(329)

120. Baker HG. Characteristics and modes of origin of weeds. In: Baker HG, Stebbins GL, editors. The genetics of colonizing species. New York, USA Academic Press; 1965. p. 147-68.

121. Catford J, Jannson R, Nillson C. Reducing redundancy in invasion ecology by integrating hypotheses into a single theoretical framework. Divers Distrib. 2009:15:22-40.

122. Kolar CS, Lodge DM. Progress in invasion biology: predicting invaders. Trends Ecol Evol. 2001;16:199-204.

123. Rejmánek M, Richardson DM. What attributes make some plant species more invasive? Ecology. 1996;77:1655-61.

124. Richardson DM, Cowling RM. In: van Wilgen BW, Richardson DM, Kruger FJ, van Hensbergen $\mathrm{HJ}$, editors. Why is mountain fynbos invasible and which species invade? Fire in South African Mountain Fynbos. Berlin, Germany: Springer-Verlag; 1992. p. 161-89.

125. Colautti RI, Ricciardi A, Grigorovich IA, Macisaac HJ. Is invasion success explained by the enemy release hypothesis? Ecol Lett. 2004;7:721-33.

126. Keane RM, Crawley MJ. Exotic plant invasions and the enemy release hypothesis. Trends Ecol Evol. 2002;17:164-70.

127. Joshi J, Vrieling K. The enemy release and EICA hypothesis revisited: incorporating the fundamental difference between specialist and generalist herbivores. Ecol Lett. 2005:8:704-14.

128. van Kleunen M, Weber E, Fischer M. A meta-analysis of trait differences between invasive and non-invasive plant species. Ecol Lett. 2010;13:235-45.

129. Pysek P, Richardson D. Traits associated with invasiveness in alien plants: where do we stand? In: Nentwig W, editor. Biological Invasions. Berlin Heidelberg: Springer; 2008. p. 97-125

130. Crawley M, Harvey P, Purvis A. Comparative ecology of the native and alien floras of the British Isles. Phil Trans Royal Soc London B: Biol Sci. 1996;351: 1251-9.

131. Williamson M, Fitter $A$. The characters of successful invaders. Biol Conserv. 1996:78:163-70.

132. Goodwin B, McAllister A, Fahrig L. Predicting invasiveness of plant species based on biological information. Conserv Biol. 1999;13:422-6.

133. Cadotte M, Lovett-Doust J. Ecological and taxonomic differences between native and introduced plants of southwestern Ontario. Ecoscience. 2001;8:230-8.

134. Lake JC, Leishman MR. Invasion success of exotic plants in natural ecosystems: the role of disturbance, plant attributes and freedom from herbivores. Biol Conserv. 2004;117:215-26.

135. Lloret F, Medail F, Brundu G, Carnarda I, Moragues E, Rita J, Lambdon P, Hulme P. Species attributes and invasion success by alien plants on Mediterranean islands. J Ecol. 2005;93:512-20.

136. Cadotte M, Murray B, Lovett-Doust J. Evolutionary and ecological influences of plant invader success in the flora of Ontario. Ecoscience. 2006:13:388-95.

137. Pysek P, Sádlo J, Mandák B, Jarosík V. Czech alien flora and the historical pattern of it formation: what came first to central Europe? Oecologia. 2003: 135:122-30. 
138. Cavaleri M, Sack L. Comparative water use of native and invasive plants at multiple scales: a global meta-analysis. Ecology. 2010;91:2705-15.

139. Wilson CG, Flanagan CJ, Gillet JD. The phytophagous insect fauna of the introduced shrub Mimosa pigra in northern Australia and its relevance to biological control. Environ Entomol. 1990;19:776-84.

140. McClay AS, Palmer WA, Bennett FD Pullen RK. Phytophagous arthropods associated with Parthenium hysterophorus (Asteraceae) in North America. Environ Entomol. 1995;24:796-809.

141. Liu H, Stiling P. Testing the enemy release hypothesis: a review and metaanalysis. Biol Inv. 2006;8:1535-45.

142. Gerber E, Krebs C, Murrell C, Moretti M, Rocklin R, Schaffner U. Exotic invasive knotweeds (Fallopia spp.) negatively affect native plant and invertebrate assemblages in European riparian habitats. Biol Conserv. 2008;141:646-54.

143. Perre P, Loyola RD, Lewinsohn TM. Insects in urban plants: contrasting the flower head feeding assemblages on native and exotic hosts. Urban Ecosyst. 2011;14:711-22.

144. Tanner RA, Varia S, Eschen R, Wood S, Murphy S, Gange AC. Impacts of an invasive non-native annual weed, Impatiens glandulifera, on above- and below-ground invertebrate communities in the United Kingdom. PLoS One. 2013;8(6):e67271

145. Hengstum T, Hooftman DA, Oostermeijer JGB, Tienderen PH. Impact of plant invasions on local arthropod communities: a meta-analysis. J Ecol. 2014;102:4-11.

146. JRW D, Anderson DM, Milton SJ, Anderson TA. Avian assemblages in Acacia and Prosopis drainage line woodland in the Kalahari, South Africa. J Arid Environ. 2002;51:1-19.

147. Scheiman DM, Bollinger EK, Johnson DH. Effects of leafy spurge infestation on grassland bird. J Wildlife Manage. 2003;67:15-121.

148. Lloyd JD, Martin TE. Reproductive success of chestnut-collared longspurs in native and exotic grassland. Condor. 2005;107:363-74.

149. Shanungu GK. Management of the invasive Mimosa pigra L. in Lochinvar National Park, Zambia. Biodiversity. 2009;10:56-60.

150. Nikbakhtzadeh M, Terbot J, Foster W. Survival value and sugar access of four east African plant species attractive to a laboratory strain of sympatric Anopheles gambiae (Diptera: Culicidae). J Med Entomol. 2016; 53:1105-11

151. Nyasembe VO, Cheseto X, Kaplan F, Foster WA, Teal PEA, Tumlinson JH, Borgemeister $C$, Torto $B$. The invasive American weed Parthenium hysterophorus can negatively impact malaria control in Africa. PLoS One. 2015;10(9):e0137836.

152. Pimentel D. Environmental and economic costs of the application of pesticides primarily in the United States. Environ Dev Sustain. 2005;7:229-52.

153. Annett R, Habibi HR, Hontela A. Impact of glyphosate and glyphosate-based herbicides on the freshwater environment. J App Toxic. 2014;34:458-79.

154. Julien MH. Griffiths MW editors. Biological control of weeds. A world catalogue of agents and their target weeds, 4th ed. Wallingford, UK: CABI Publishing; 1998.

155. Winston RL, Shwarzländer M, Hinz HL, Day MD, MJW C, Julien MH, editors. Biological Control of Weeds: A World Catalogue of Agents and their Target Weeds, $5^{\text {th }}$ ed. Morgantown. West Virginia, USA: USDA Forest Service, Forest Health, Technology Enterprise FHTET-2014-04.838; 2014.

156. Fowler SV. Trivial and political reasons for the failure of classical biological control of weeds: A personal view: In: Spencer NR, editor. Proceedings of the X International Symposium on Biological Control of Weeds. Bozeman, Montana, USA: Montana State University; 2000. p. 169-172.

157. Fowler SV, Syrett P, Hill RL. Success and safety in the biological control of environmental weeds in New Zealand. Austral Ecol. 2000;25:553-62.

158. Zimmerman $\mathrm{HH}$, Moran VC, Hoffman HJ. Biological control in the management of invasive alien plants in south African and the role of the working for water programme. S Afr J Sci. 2004;100:34-40.

159. McFayden REC. Successes in biological control of weeds. In: Spencer NR editor. Proceedings of the Xth International Symposium on Biological Control of Weeds. Bozeman: Montana State University; 2000. p. 3-14.

160. Markin GP, Lai PY, Funasaki GY. Status of biological control of weeds in Hawaii and implications for managing native ecosystems. In: Stone CP, Smith CW, Tunison JT, editors. Alien plant invasions in native ecosystems of Hawaii, i: management and research. Honolulu Hawaii: University of Hawaii Cooperative National Park Resources Studies Unit; 1992. p. 446-82.

161. Hoffmann JH. Biological control of weeds: the way forward, a South African perspective. In: Stirton CH, editor. Proceedings of the BCPC Symposium: Weeds in a Changing World. Farnham, UK: British Crop Protection Council Book no. 64; 1995. p. 77-89.
162. Annecke DP, Moran VC. Critical reviews of biological pest control in South Africa. 2. The prickly pear, Opunlia ficus-indica (L.) miller. J Entomol Soc SA 1978;41:161-88.

163. Moran VC, Zimmermann HG. Biological control of cactus weeds of minor importance in South Africa. Agric Ecosyst Environ. 1991;37:37-55.

164. De Lange WJ, van Wilgen BW. An economic assessment of the contribution of weed biological control to the management of invasive alien plants and to the protection of ecosystem services in South Africa. Biol Inv. 2010;12:4113-24.

165. Neuenschwander $\mathrm{P}$, Julien MH, Center TD, Hill MP. Pistia stratiotes L. (Araceae). In: Muniappan R, Reddy GVP, Raman A, editors. Biological Control of Tropical Weeds Using Arthropods. Cambridge: Cambridge University Press; 2009. p. 332-352.

166. Coetzee JA, Hill MP, Byrne MJ, Bownes A. A review of the biological control programmes on Eichhornia crassipes (C. Mart.) Solms (Pontederiaceae), Salvinia molesta D. S. Mitch. (Salviniaceae), Pistia stratiotes L. (Araceae), Myriophyllum aquaticum (Vell.) Verdc. (Haloragaceae) and Azolla filiculoides Lam. (Azollaceae) in South Africa. Afr Entomol. 2011;19:451-68.

167. McConnachie AJ, de Wit MP, Hill MP, Byrne MJ. Economic evaluation of the successful biological control of Azolla filiculoides in South Africa. Biol Control. 2003;28:25-32

168. Fernández Carrillo JL, Fernández Carrillo E, Alonso-Zarazaga MA. Primera cita de Stenopelmus rufinasus Gyllenhal, 1835 en la Península Ibérica (Coleoptera, Erirhinidae). Graellsia. 2005;61:39-140.

169. Oliver JD. A Review of the biology of giant salvinia (Salvinia Molesta Mitchell). J Aquat Plant Manage. 1993;31:227-31.

170. Cilliers CJ. Biological control of parrot's feather, Myriophyllum aquaticum (Vell.) Verdc. (Haloragaceae), in South Africa. Afri Entomol Mem. 1999;1: $113-8$.

171. Julien M, Sosa AJ, Chan R, Schooler S, Traversa G. Alternanthera philoxeroides (Martius) Grisebach-alligator weed. In: Julien M, McFadyen R, Cullen J, editors. Biological control of weeds in Australia. Melbourne, Australia: CSIRO Publishing; 2012. p. 43-51.

172. Van Klinken RD, Fichera G, Cordo H. Targeting biological control across diverse landscapes: the release, establishment and early success of two insects on mesquite (Prosopis) in rangeland Australia. Biol Control. 2003;26: 8-20.

173. Van Klinken R. Prosopis spp. - mesquite. In: Julien M, McFadyen R, Cullen J, editors. Biological Control of Weeds in Australia. Melbourne, Australia: CISRO Publishing; 2012. p. 477-85.

174. Impson FAC, Kleinjan CA, Hoffmann JH, Post JA, Wood AR. Biological control of Australian Acacia species and Paraserianthes lophantha (Willd.) Nielsen (Mimosaceae) in South Africa. Afr Entomol. 2011;19:186-207.

175. Dhileepan K. Biological control of parthenium (Parthenium hysterophorus) in Australian rangeland translates to improved grass production. Weed Sci. 2007:55:497-501.

176. Greathead DJ. Benefits and risks of classical biological control. In: T. Hokkanen HMT, Lynch JM, editors. Biological Control: Benefits and Risks. Cambridge: Cambridge University Press; 1995. p. 55-63.

177. Higgens SL, Turpie LK, Costanza R, Cowling RM, Le Maitre DC, Marais C, et al. An ecological economic simulation model of mountain fynbos ecosystems. Dynamics, valuation and management. Ecol Econ. 1997;22: 155-69.

178. Lovell SJ, Stone SF, Fernandez L. The economic impacts of aquatic invasive species: a review of the literature. Agric Res Econ Rev. 2006;35:195-208.

179. De Wit M, Crookes D, van Wilgen BW. Conflicts of interest in environmental management: estimating the costs and benefits of a tree invasion. Biol Inv. 2001;3:167-78.

180. Brown P, Daigneault A. Cost-benefit analysis of managing the invasive African tulip tree (Spathodea campanulata) in the Pacific. Environ Sci Pol. 2014;39:65-76.

181. Zavaleta E. Valuing ecosystem services lost to Tamarix invasion in the United States. In: Mooney HA, Hobbs RJ, editors. Invasive species in a changing world. Washington, DC: Island Press; 2000. p. 261-300.

182. Zavaleta E. The economic value of controlling an invasive shrub. Ambio. 2000;29:462-7.

183. Van Wilgen BW, de Witt MP, Anderson HJ, le Maitre DC, Kotze IM, Ndala S, et al. Costs and benefits of biological control of invasive alien plants. Case studies from South Africa. S Afr J Sci. 2004;100:113-22. 
184. Versfeld DB, Le Maitre DC, Chapman RA. Alien invading plants and water resources in South Africa: a preliminary assessment. WRC Report No. TT 99/ 98 abd CSIR No. ENV/S-C 97154; 1998.

185. Page AR, Lacey KL. Economic Impact Assessment of Australian Weed Biological Control. Australia: CRC for Australian Weed Management Technical Series. 10; 2006.

186. De Groote H, Ajuonu O, Attignon S, Djessou R, Neuenschwander P. Economic impact of biological control of water hyacinth in southern Benin. Ecol Econ. 2003;45:105-17.

187. Gardner AM, Muturi EJ, Overmier LD, Allan BF. Large-scale removal of invasive honeysuckle decreases mosquito and avian abundance. EcoHealth. 2017;14(4):750-61.

188. Ma BO, Roitberg BD. The role of resource availability and state-dependence in the foraging strategy of blood-feeding mosquitoes. Evol Ecol Res. 2008; 10:1111-30

Submit your next manuscript to BioMed Central and we will help you at every step:

- We accept pre-submission inquiries

- Our selector tool helps you to find the most relevant journal

- We provide round the clock customer support

- Convenient online submission

- Thorough peer review

- Inclusion in PubMed and all major indexing services

- Maximum visibility for your research

Submit your manuscript at www.biomedcentral.com/submit 